\title{
Secondary glaucoma associated with bilateral Aspergillus niger endophthalmitis in an HIV-positive patient: case report
}

\author{
Glaucoma secundárioa endoftalmitebilateral por Aspergillus niger em paciente \\ HIV-positivo: relato decaso
}

\author{
Jayter Silva Paula ${ }^{1}$ \\ Agostinho Bryk Junior ${ }^{2}$ \\ Argemiro Lauretti Filho ${ }^{3}$ \\ Erasmo Romão ${ }^{4}$
}

\begin{tabular}{l} 
ABSTRACT \\
\hline Aspergillus endophthalmitis is usually related to systemic or local disse- \\
mination in immunosuppressed subjects. The authors report a rare case of \\
severe bilateral glaucoma secondary to an intraocular infection with \\
Aspergillus niger, in the absence of any detectable focus of aspergillosis, \\
in an HIV-infected patient. There were no confirming signs of injection \\
drug use, and the agent was isolated after inoculation in experimental \\
animals. This case shows that Aspergillus endophthalmitis should be \\
considered in non-injecting drug users and HIV-infected patients even in \\
the absence of systemic aspergillosis.
\end{tabular}

Keywords: Aspergillus niger/isolation \& purification; Endophthalmitis/complications; Glaucoma/etiology; Eye infections, fungal; HIV; Immunocompromised host; Case reports [publication type]

\section{INTRODUCTION}

Aspergillus is a fungus with septate hyphae about 2 to $4 \mu \mathrm{m}$ in diameter identified on the basis of its macroscopic and microscopic aspect in cultu$\mathrm{re}^{(1)}$. Spore inhalation is common but the disease is rare. However, massive spore inhalation by a healthy person can cause diffuse acute pneumonia ${ }^{(1)}$. Patients with aspergillosis usually present some type of immunodeficien$c y^{(1)}$. Penetrating trauma to the eye, cataract surgery and hematogenic dissemination are conditions associated with Aspergillus-induced endophthalmitis $^{(2-3)}$. We report here a case of severe bilateral glaucoma secondary to an intraocular infection with Aspergillus niger.

\section{CASE REPORT}

A 27-year-old white woman was referred to ophthalmological examination, with a progressive bilateral decrease of visual acuity that culminated in total loss of vision. The patient denied any previous ocular disease, traumatic injury or injection drug use. Her husband was sexually promiscuous.

Ophthalmologic examination revealed no light perception in the right eye (OD) and perception of hand movements in the left eye (OS). Biomicroscopy revealed an anterior chamber with mild cellularity in both eyes. Intraocular pressure was $65 \mathrm{mmHg}$ in the OD and $60 \mathrm{mmHg}$ in the OS. Fundoscopy revealed total excavation of the optic disc in the OD; details could not be observed in the OS because of vitreitis (Figure 1A and B). 


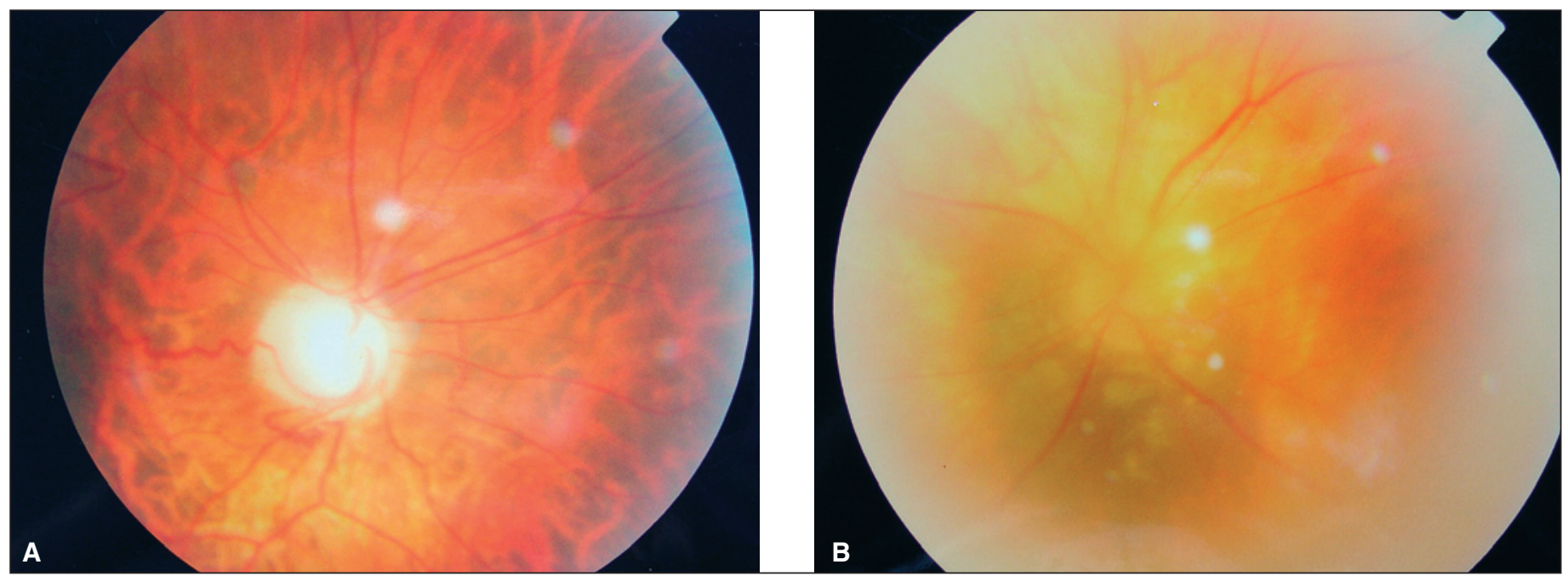

Figure 1 - A: Fundus photography of the right eye showing total excavation of the optic disc; B: Fundus photography of the left eye showing vitreitis and small yellowish lesions surrounding the optic disc

Cultures of OS aqueous humor were positive for Aspergillus niger. Material obtained from those cultures was inoculated into the posterior segment of a rabbit eye, with growth and isolation of the same agent (Figure 2).

Limbic base trabeculectomy was performed in the OS without untoward events. During the investigation of the causes of immunodeficiency, HIV-1 antibodies were detected in two different examinations. Radiographic and serologic evaluation and blood culture for fungi were negative. No additional examinations or specific treatment could be performed because the patient did not return for the scheduled visits.

\section{DISCUSSION}

In most cases of systemic Aspergillus involvement the patients present some type of immunodepression and, among

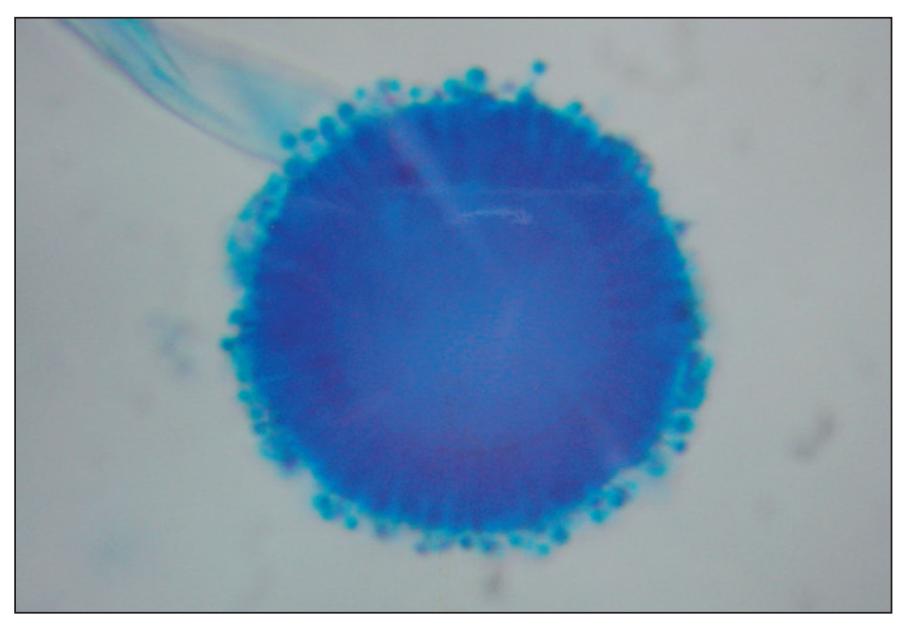

Figure 2 - Microphotography of lactophenol cotton blue stain showing the presence of Aspergillus niger from the vitreous of an inoculated rabbit (400x)
HIV-infected patients, those with $\mathrm{T} \mathrm{CD}_{4}{ }^{+}$counts $<50 / \mathrm{mm}$ are at higher risk to suffer aspergillosis ${ }^{(1)}$.

Aspergillus endophthalmitis is usually related to systemic or local dissemination, as observed in injection drug users ${ }^{(4)}$ and in immunosuppressed subjects ${ }^{(5-6)}$ or after cataract surge$\mathrm{ry}^{(2)}$. In the present case, no primary foci of hematogenic dissemination were detected, and the patient had no history of surgical procedures.

Since in the present case, as also reported in the literatu$\mathrm{re}^{(6)}$, there were no confirming signs of the use of drugs, we may raise the hypothesis of endogenous endophthalmitis from a rare site, perhaps with already resolved infection.

The Aspergillus hyphae are observed in the slide, but only culture can determine and confirm the species ${ }^{(1)}$. In the present case, the agent was isolated after inoculation in experimental animals, thus completing the Koch postulate.

Although the association of glaucoma and endogenous Aspergillus endophthalmitis reported here in an HIV-positive patient is a rare occurrence, the search for fungal agents even in the absence of primary foci is of great relevance in clinical and laboratory terms.

\section{RESUMO}

Endoftalmite por Aspergillus é geralmente relacionada à disseminação local ou sistêmica do agente em indivíduos imunocomprometidos. Os autores relatam um caso raro de glaucoma bilateral grave secundário a uma infecção intra-ocular por Aspergillus niger, na ausência de qualquer foco detectável de aspergilose em paciente HIV-positivo. Foram afastados sinais e antecedentes de uso de drogas injetáveis e o agente foi isolado após inoculação em animais experimentais. Este caso demonstra que a endoftalmite por Aspergillus deve ser considerada em pacientes HIV-positivos não-usuários de drogas injetáveis, mesmo na ausência de aspergilose sistêmica. 
Descritores: Aspergillus niger/isolamento \& purificação; Endoftalmite/complicações; Glaucoma/etiologia; Infecções oculares fúngicas; HIV; Hospedeiro imunocomprometido; Relatos de casos [tipo de publicação]

\section{REFERENCES}

1. Bennett JE. Aspergilose. In: Fauci AS, Braunwald E, Isselbacher KJ, Martin WJB, Kasper DL, Hauser SL, et al, editores. Harrison Medicina Interna. 14a ed. Rio de Janeiro: McGraw - Hill Interamericana do Brasil; 1998. p.1238-9.
2. Brar GS, Ram J, Kaushik S, Chakraborti A, Dogra MR, Gupta A. Aspergillus niger endophthalmitis after cataract surgery. J Cataract Refract Surg. 2002;28 (10): 1882-3.

3. Feman SS, Nichols JC, Chung SM, Theobald TA. Endophthalmitis in patients with disseminated fungal disease. Trans Am Ophthalmol Soc. 2002;100: 67-70; discussion 71-1

4. Kim RW, Juzych MS, Eliott D. Ocular manifestations of injection drug use. Infect Dis Clin North Am. 2002;16(3):607-22.

5. Hara KS, Ryu JH, Lie JT, Roberts GD. Disseminated Aspergillus terreus infection in immunocompromised hosts. Mayo Clin Proc. 1989;64(7):770-5.

6. Machado O de O, Gonçalves R, Fernandes EM, Campos WR, Orefice F, Curi AL. Bilateral Aspergillus endophthalmitis in a patient with chronic lymphocytic leukaemia. Br J Ophthalmol. 2003;87(11):1429-30.

\section{2 a 04 de Novembro de 2006}

Centro de Convenções do Ouro Minas Palace Hotel

Belo Horizonte - MG

\section{INFORMAÇÕES}

Tel./Fax: (31) 3291-9899

E-mail: hsgeraldo@consulteventos.com.br

Home page: www.hospitalsaogeraldo.com.br 